\title{
BEHAVIOR OF SELENIUM IN SILICIC VEIN ROCKS AND NEAR GRANITIC CONTACTS
}

\author{
Tapio Koljonen
}

\begin{abstract}
Koljonen, TApio, 1974: Behavior of selenium in silicic vein rocks and near granitic contacts. Bull. Geol. Soc. Finland 46, 133-138.

Selenium is very mobile in the conditions under which granitic rocks are crystallized and is depleted in silicic plutonic rocks and in pegmatites. It tends to separate from magma and be enriched into gaseous phase. The concentrations found in migmatized and fenitized rocks are much lower than the mean in metamorphic rocks. Therefore selenium appears to migrate along fractures early in the metamorphic process and most of it before anatectic melts are formed.

The selenium released from magma or by metamorphism from bedrock may later, with sulfur, form metasomatic ores and low temperature mineralizations, or it may appear at the surface in volcanic emanations and hot springs. Iron prevents to some extent the migration of selenium from magmatic melts and rocks.
\end{abstract}

Tapio Koljonen, Department of Geology and Mineralogy, University of Helsinki, SF-00170 Helsinki 17, Finland.

\section{Introduction}

The behavior of selenium during endogenic processes is similar to that of sulfur. It is very mobile and is enriches into hydrothermal and even telethermal sulfidic ores with $\mathrm{Cu}, \mathrm{Ag}, \mathrm{Au}$, $\mathrm{Hg}, \mathrm{Pb}, \mathrm{Sb}, \mathrm{Bi}, \mathrm{Te}$, and $\mathrm{U}$. Sulfur usually predominates and only in Lucky Boy Mine in the USA (Becker 1888; McCaskey 1912) have selenides (onofrite $\mathrm{Hg}(\mathrm{S}, \mathrm{Se})$, and tiemannite $\mathrm{HgSe}$ ) been the main ore minerals. The contents of sulfides from different kinds of formations have been studied by Sindeeva (1964) and Tischendorf (1966).

During the differentiation of rocks, Se tends to accompany iron (Koljonen 1973a). It is depleted in peridotites and especially in dunites but is enriched in melanocratic gabbros (average $108 \mathrm{ppb}$ ). The concentration decreases in calcalkalic rocks as the silica content increases, being in granites often under $10 \mathrm{ppb}$ (average $25 \mathrm{ppb}$ ). In pegmatites the concentration increases slowly, step by step, as the crystallization temperature decreases and Se can be found low-temperature mineral deposits. Its is especially enriched into hot springs (Zies 1929; Vaupell 1938; Roberts 1940; Koljonen 1973a) and into volcanic emanations (Zambonini and Coniglio 1925; Geilmann and Biltz 1931; Byers et al. 1936; Friend and Allachin 1941; Di Franco 1942, Kaplan et al. 1969).

In this study the behavior of $\mathrm{Se}$ is investigated 
near the contact of granites with country rock, and in pegmatites and other silicic vein rocks, mostly from Finland.

\section{Samples}

Most of the analyses set out in Table 1 have been presented earlier in the author's report $(1973 a, b)$ of Se contents in igneous and metamorphic rocks. Since geological references are to be found in those papers, only supplementary information is added in Table 1. Rocks from the same locality are displayed as a group.

In the following the behavior of selenium near contacts of various types is briefly reviewed.

\section{Contacts of granite and metamorphic country rock (Table 1, Groups 1-4)}

Selenium is very mobile during the emplacement of granitic rocks and is depleted in granites. In orbicular granites, which are zoned enclaves in granites ( $c f$. Simonen 1941; Didier 1973), and which in the author's opinion are hybrids formed when silicic magma comes into contact with more basic country rock, the concentration is higher than the average in granites. In Espoo (Table 1, Group 1) the content is decreased in pyroxene gneiss when granitization is apparent and is low in orbicular granite; but in both cases it is still higher than in granites. In Kuru (Table 1 , Group 2) the content in orbicular granite is higher than in granite and lower than in gabbro from the same area. Selenium contents support the origin of the these rocks through the assimilation of country rock.

In the rapakivi granites there is more $\mathrm{Se}(56$ $\mathrm{ppb}$ ) than the average in granites. Selenium content is low in the contact zone (Table 1, Groups 3, and 4) but seems to have increased a little, metasomatically, near the immediate contact.

Around Wiborg massif, to which Suomenniemi, Mäntyharju and Onas granites belong as small satellites, is a thermometamorphic aureole about five kilometers broad (Vorma 1972). In this, microcline has been transformed into orthoclase and the country rock near the contacts metamorphosed in places to hornfelses. With the increased temperature during the emplacement of rapakivi granites, selenium seems to have migrated out from the country rock ( $c f$. Table 1 , Nos. 8, 11, and 88).

Alkalic rocks and carbonatites contain little Se. The concentration in the fenite and the surrounding gneisses in the carbonatite complex of Siilinjärvi is low (Table 1, Group 14) as it is in syenites, which probably originated in part through metasomatism.

\section{Contacts of silicic dykes with plutonic country rock (Table 1, Groups 5-14)}

In silicic dykes Se concentration is usually lower than in the country rock when the content in the country rock is high (average in igneous rocks $48 \mathrm{ppb}$ ), but some Se is found even when the content is low. In this last case the content over a large area is probably being reflected.

The selenium contents in a small granitic even-grained vein, which probably is a wholly recrystallized old fracture, and in homogenous granite (Table 1, Nos. 21 and 22) were found to be the same.

\section{Contacts of silicic vein rock with metamor- phic country rock (Table 1, Groups 15-27)}

On the average, metamorphic rocks contain more selenium than plutonic rocks do. This is reflected in silicic veins, which contain more Se in areas where metamorphic rocks prevail. Concentration is greatest in veins situated in sulfide rich gneiss or in black schist (Table 1, Nos. 41, and 60). In those located in highly metamorphic areas (e.g. migmatized), as in southern Finland (cf. Table 1, Nos. 52, 54, and 56), Se content is less than in those in areas where the grade of metamorphism is low (cf. Table 1, Nos. 63, 65, and 67). 
Selenium seems to have migrated along fractures before the emplacement of the pegmatite dykes and its concentration is decreased in the country rock near the vein (Table 1, Groups 16 and 26). In mica schist (Table 1, Groups 23 and 24) selenium has migrated with quartz to small veinlets, although in magmatic or anatectic conditions it does not accompany silica. In migmatized rocks the highest concentration is found in the dark colored part (Table 1, Group 16) but in both melanocratic and leucocratic parts it is less than in unmigmatized rock.

Probably most or the selenium found in pegmatites and in silicic veins has entered the dyke from the country rock. Selenium concentrated in late volatile differentiates of cooling magma seems to have separated into hydrothermal solutions and migrated in advance much before the pegmatitic solutions. Nevertheless, it is possible that the hydrothermal solutions earlier increased the content in the country rock.

\section{Contact of igneous and metasomatic rocks (Table 1, Group 28)}

The antophyllite asbestos deposits at Paakkila are rootless lensses in gneiss (Wiik 1953, p. 10) formed through hydrothermal alteration of ultrabasic rocks by solutions rich in selenium. Younger Maarianvaara granite cuts the formation. Selenium content in the deposit decreases near the contact and the pegmatite seems to be contaminated with selenium migrating out from the country rock.

\section{Dynamometamorphic rock (Table 1, Group 29)}

The blastomylonite (No. 83) is a dark-colored glassy vein in gneiss, $30-\mathrm{cm}$ wide, which originated when country rock was broken in movements. Selenium content in it is much higher than in the surrounding area, probably indicating that selenium migrated into the fracture during the movements. The phenomenon is analogous to the formation of sulfide films on the walls of joints.

Behavior of selenium in fissures that are more or less open to the surface (Table 1, Groups $30-34$ )

Near the surface, where temperature and pressure decrease, selenium separates in gaseous form from the cooling and crystallizing magma and is strongly enriched into volcanic emanations. The selenium content in soils of volcanic areas is commonly high (Koljonen 1973a, p. 18).

In silicic vein rocks formed near the surface, selenium content is very low. In the granophyre and leucocratic gabbro from Iceland (Table 1, Group 30) no Se is found, although the average in basalts is $150 \mathrm{ppb}$ (17 specimens) and in rhyolites $120 \mathrm{ppb}$ (11 specimens). Also the content in basic veins in Pellinki and in the porphyry veins (9 specimens) associated with rapakivi granites (average $56 \mathrm{ppb}$ ) is under $10 \mathrm{ppb}$. However, in one sample, from the contact of a quartz porphyry in Wiborg massif, $110 \mathrm{ppb}$ Se was found.

\section{Summary}

During the emplacement of plutonic rock, a great part of the selenium present in the bedrock tends to migrate out of the system. Metasomatism occurs, but since Se concentration in plutonic rocks is usually low, the increase affects only the immediate contact.

Selenium released from magma migrates in hydrothermal solutions before the pegmatitic phase and only traces are found in pegmatites. Nevertheless, the content in pegmatites is often greater than in granites. Selenium is usually absent ( $<10 \mathrm{ppb}$ ) from large granitic dykes, but country rock looses part of its Se to the dykes when the content in it is high (Fig. 1). When the silicic veins are small, Se content reflects the concentration found in bedrock. The 
TABle 1

Selenium content in silicic vein rocks and near granitic contacts

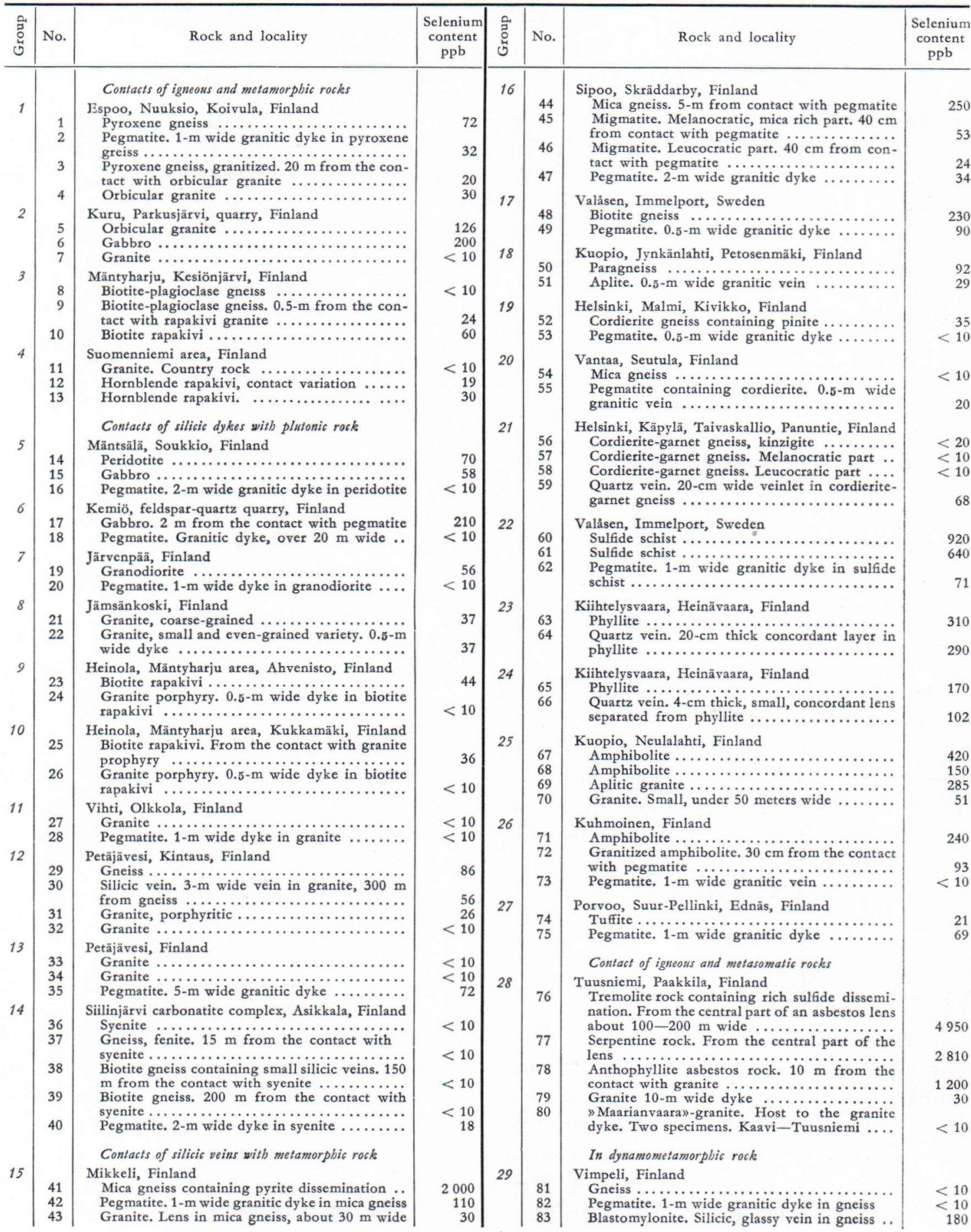




\begin{tabular}{|c|c|c|c|c|c|c|c|}
\hline ड़े & No. & Rock and locality & $\begin{array}{c}\text { Selenium } \\
\text { content } \\
\mathrm{ppb}\end{array}$ & 芯 & No. & Rock and locality & $\begin{array}{c}\text { Selenium } \\
\text { content } \\
\text { ppb }\end{array}$ \\
\hline 30 & & $\begin{array}{l}\text { In dyke rocks with more or less open cbannels to surface } \\
\text { Iceland } \\
\text { Average in basalts (17 specimens) ........... }\end{array}$ & & & 89 & $\begin{array}{l}\text { Basic dyke. } 0.5-\mathrm{m} \text { wide dyke in metavolcanics } \\
\text { (Laitala } 1973 \text {, p. } 69-70) \ldots \ldots \ldots \ldots \ldots \ldots \ldots\end{array}$ & $<10$ \\
\hline & $\begin{array}{l}84 \\
85\end{array}$ & $\begin{array}{l}\text { Average in basalts }(17 \text { specimens }) \\
\text { Average in rhyolites and obsidians }(11 \text { speci- } \\
\text { mens) } \ldots \ldots \ldots \ldots \ldots \ldots \ldots \ldots \ldots \ldots \ldots \ldots \ldots \ldots \ldots \ldots\end{array}$ & $\begin{array}{l}150 \\
120\end{array}$ & 32 & $\begin{array}{l}90 \\
91\end{array}$ & $\begin{array}{l}\text { Suomenniemi area, Finland } \\
\quad \text { Rapakivi }(2 \text { specimens) } \ldots \ldots \ldots \ldots \ldots \ldots \\
\text { Porphyry aplite in rapakivi }(2 \text { specimens }) \ldots\end{array}$ & $\begin{array}{r}25 \\
<10\end{array}$ \\
\hline & $\begin{array}{l}86 \\
87\end{array}$ & 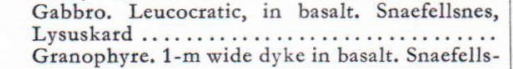 & $<10$ & 33 & 92 & $\begin{array}{l}\text { Mäntyharju area, Finland } \\
\quad \text { Rapakivi ( } 4 \text { specimens) } \ldots \ldots \ldots \ldots \ldots \\
\text { Granite porphyry in rapakivi }(2 \text { specime }\end{array}$ & 66 \\
\hline 31 & 88 & 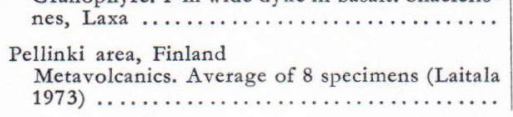 & $<10$ & 34 & $\begin{array}{l}94 \\
95\end{array}$ & 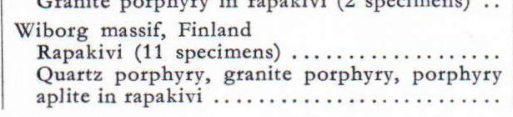 & $\begin{array}{r}< \\
\quad 65 \\
<10\end{array}$ \\
\hline
\end{tabular}

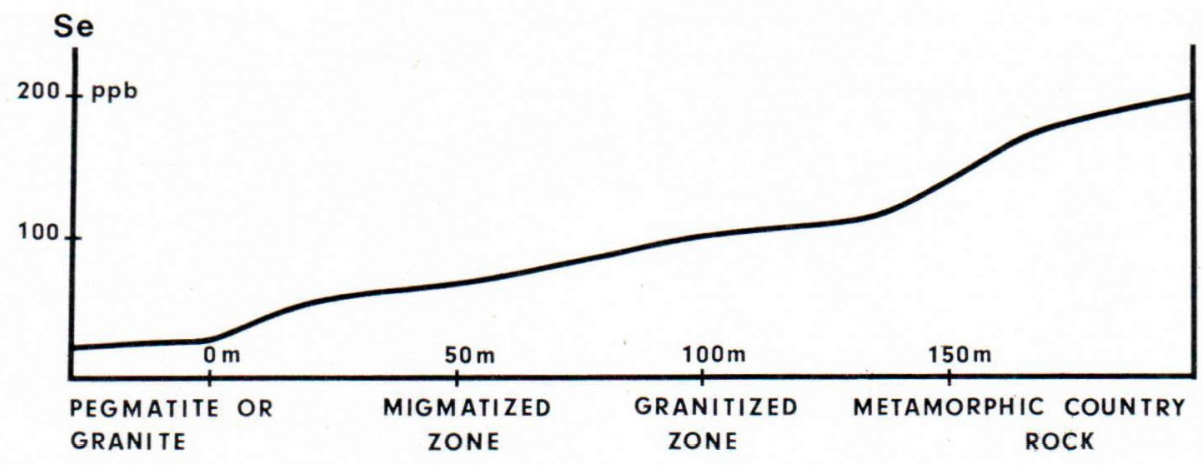

Fig. 1. Schematic representation of the variation in selenium content in country rock near contacts with pegmatite (or granite). Distances are estimates from distances that varied from meters to hundrets of meters.

greatest concentrations are found in small quartz secretions, indicating early mobilization during metamorphism. Selenium also migrates during tectonic movements and tends to accumulate in fissures or concentrates with sulfides as ore dissemination in suitable areas of country rock.

When the fissure channel is open to the surface, as in volcanic areas, the pressure in the magma decreases. Gaseous selenium escapes along with other volatile substances, resulting in a decreased Se content in the vein. The high silica content of magma encourages the process because silicic magma is viscous and advances sluggishly.

\section{REFERENCES}

BECKer, G. F. (1888) Geology of the quicksilver deposits of the Pacific slope, with an atlas. U. S. Geol. Surv., Mon. 13: 385-386.

Byers, H. G., Williams, K. T. and Lakin, H. W. (1936) Selenium in Hawaii and its probable source in the United States. Ind. Eng. Chem., Ind. Ed. 28: 821-823.

Didier, J. (1973) Granites and their enclaves. Developments in Petrology 3. Elsevier Scientific Publishing Company. Amsterdam/London/New York.
Di Franco, S. (1942) Mt. Etna's mineralogy. Accad. Gioenia Sci. Nat. Catania Atti 5: 1-175 (Chem. Abs. 42, Col. 491).

Friend, J. N. and Allachin, J. P. (1941) The selenium and tellurium contents of sulfur from Krisuvik, Iceland. Miner. Mag. 26: 9-10.

GeilmanN, W. and Biltz, W. (1931) Über die Zusammensetzung vulkanischen Schwefels von Papandajan(West-Java). Z. Anorg. Allg. Chem. 197:4 22-428. 
Kaplan, I. R., Sweeney, R. E. and Nissenbaum, A. (1969) Sulfur isotope studies on Red Sea geothermal brines and sediments. (Ed. Degens, E. T. and Ross, D. A.): Hot brines and recent heavy metal deposits in the Red Sea. Springer-Verlag. New York.

Koljonen, T. (1973a) Selenium in certain igneous rocks. Bull. Geol. Soc. Finland 45: 9-22.

- (1973b) Selenium in certain metamorphic rocks. Bull. Geol. Soc. Finland 45: 107-117.

Laitala, M. (1973) On the Precambrian bedrock and its structure in the Pellinge region, South Finland. Geol. Surv. Finland Bull. 264.

McCaskey, H. D. (1912) Quicksilver. U. S. Geol. Surv., Mineral Resources U. S., 1911, 1: 914-915.

Roberts, R. J. (1940) Quicksilver deposit at Buckskin Peak, National Mining district, Humboldt County, Nev. U. S. Geol. Surv., Bull. 922-E.

SIMONEN, A. (1941) Orbicular rocks in Kemijärvi and Esbo. Bull. Comm. Géol. Finlande 126: 107-140.

Sindeeva, N. D. (1964) Mineralogy and types of deposits of selenium and tellurium. Interscience Publishers. New York/London/Sydney.
Trschendorf, G. (1966) Zur Verteilung des Selens in Sulfiden. Freib. Forschungsh. C 208.

Vaupell, C. W. (1938) Mercury deposits of Huitzuco, Guerrero, Mexico. Am. Inst. Min. Metall. Eng., Tech. Pub. 842.

Vorma, A. (1972) On the contact aureole of the Wiborg rapakivi granite massif in southeastern Finland. Geol. Surv. Finland Bull. 255.

WrIK, H. B. (1953) Composition and origin of soapstone. Bull. Comm. Géol. Finlande 165.

Zambonini, F. and Coniglio, L. (1925) The presence of soluble compounds of selenium and tellurium as products of the activity of Vesuvius. Ann. Oss. Vesuviano (3) $2: 3-6$.

Zies, E. G. (1929) The Valley of Ten Thousand Smokes; - The fumarolic incrustations and their bearing on ore deposition. Natl. Geogr. Soc. Contrib., Tech. Pap. 1.

Manucript received, February 12, 1974. 